\title{
BROWER AND SAENZ ON DIVINE TRUTHMAKER SIMPLICITY
}

\begin{abstract}
James R. Beebe
Jeffrey Brower has recently articulated a way to make sense of the doctrine of divine simplicity using resources from contemporary truthmaker theory. Noël Saenz has advanced two objections to Brower's account, arguing that it violates constraints on adequate metaphysical explanations at various points. I argue that Saenz's objections fail to show that Brower's account is explanatorily inadequate.
\end{abstract}

$I$.

The doctrine of divine simplicity (which finds expression in the works of Augustine, Anselm, and Aquinas, ${ }^{1}$ inter alia) is the view that God is absolutely simple, lacking any distinct metaphysical parts or constituents. This means that God is not even distinct from God's goodness, God's power, or God's wisdom, which in turn means that God's goodness is not distinct from God's power or God's wisdom. If any of these items failed to be identical, God would have components and would not be metaphysically simple after all.

Alvin Plantinga has provided the most famous contemporary articulation of the central challenges facing such a view:

There are two difficulties, one substantial and the other truly monumental. In the first place, if God is identical with each of his properties, then each of his properties is identical with each of his properties, so that he has but one property. This seems flatly incompatible with the obvious fact that God has several properties; he has both power and mercifulness, say, neither of which is identical with the other. In the second place, if God is identical with each of his properties, then since each of his properties is a property, he is a property - a self-exemplifying property. Accordingly God has just one property: himself. This view is subject to a difficulty both obvious and overwhelming. No property could have created the world; no property could be omniscient, or, indeed, know anything at all. ${ }^{2}$

\footnotetext{
${ }^{1} \mathrm{Cf}$. Brower "Making Sense of Divine Simplicity," $5 \mathrm{ff}$. for details on the historical roots of this doctrine.

2Plantinga, Does God Have a Nature?, 47.
} 
For reasons such as these, the doctrine of divine simplicity has fallen upon hard times.

In a recent attempt to articulate and defend an account of divine simplicity that avoids standard objections to it, Jeffrey Brower draws upon recent work in metaphysics on truthmaker theory. ${ }^{3}$ Truthmakers are the entities in virtue of which truths are true. ${ }^{4}$ What is unique to the current debate about truthmakers is not the idea that truths are grounded in reality but the prominence of the idea that truths can sometimes be grounded in entities themselves as opposed to (facts about) how those entities are. Taking this notion as his point of departure, Brower argues that the doctrine of divine simplicity can be explained and shown to be coherent by taking it to be the thesis that the truthmaker for divine essential predications is a metaphysically simple entity, viz., God. ${ }^{5}$ Somewhat more formally, Brower's view is the following:

(DTS) If an intrinsic essential predication of the form "God is $F$ " is true, then (i) God's F-ness exists, (ii) God's F-ness is the truthmaker of 'God is F,' and (iii) God's F-ness is identical with God.

From (ii) and (iii), it obviously follows that God is the truthmaker of "God is F." On this account, the truthmakers of "God is good" and "God is powerful" are God's goodness and God's power, each of which is identical with God. Unlike many accounts of divine simplicity that interpret God's F-ness as a property and thus make God identical with a property, DTS simply identifies God's F-ness with whatever makes "God is F" true. On DTS, what makes divine essential predications true is God himself-not facts about how God is or facts or states of affairs composed of God and properties that are distinct from God.

Although theists do not all agree about which divine predications are extrinsic or accidental, for true divine predications that are both extrinsic and accidental, Brower maintains that God alone will not be the truthmaker. The truthmaker for a statement such as "God is cursed by atheists" will be something like a fact or state of affairs composed of God, atheists, and cursing. And if God's being cursed by atheists exists, it will not be identical with God. Similarly, if the truth of "Plato is cursed by Aristotelians" requires the existence of Plato's being cursed by Aristotelians exists, the latter will be something like a fact or state of affairs composed of Plato, Aristotelians, and cursing. And this will not be identical with Plato. In the case of true intrinsic essential predications to contingent beings-e.g., "Plato is human" or "Plato is an animal" - Brower and other truthmaker theorists contend that Plato alone is the truthmaker. However, if Plato's humanity and Plato's animality exist, they will not be identical with Plato. Thus, it

3Brower, "Making Sense of Divine Simplicity" and "Simplicity and Aseity."

${ }^{4}$ See Rodriguez-Pereyra, "Truthmakers," and MacBride, "Truthmakers."

${ }^{5}$ Brower, "Making Sense of Divine Simplicity." 
is only in the case of intrinsic essential predications that different sorts of explanations will need to be given for divine and human beings.

While Brower argues that the explanation of divine simplicity in terms of truthmakers avoids various well-known objections that have been raised against the doctrine, ${ }^{6}$ Noël Saenz has recently argued that DTS faces difficulties of its own. Saenz's first objection to Brower's account of divine truthmaker simplicity maintains that DTS fails to satisfy the following important constraint on metaphysical explanation:

Truthmakers are supposed to be that which gives a metaphysical ground of truth, and grounds are supposed to be explanatory in nature. That is, if $x$ makes $<\mathrm{p}>$ true, then $x$ (or $x^{\prime}$ s existence) metaphysically explains why $<\mathrm{p}>$ is true. ${ }^{7}$

Saenz maintains that-contrary to Brower and indeed most truthmaker theorists-individuals by themselves cannot satisfy this explanatory burden:

To use Brower's example, take an intrinsic essential predication of Plato, $<$ Plato is a human $>$ and ask "what makes this proposition true?" Notice that the answer cannot be Plato. Why? Because saying that this proposition is true in virtue of Plato or that Plato makes it true, and therefore explains why it is true that he is human, is explanatorily empty. ... Plato, the concrete being, is just not rich enough to provide, on his own, a metaphysical ground of the truth of $<$ Plato is a human $>$. However, if the answer to the above question is that the proposition is true because Plato instantiates being a human, or that the state of affairs of Plato's being a human explains that it is true that Plato is a human, then I have been told something that is explanatorily helpful. ${ }^{8}$

Applying this line of argument to divine intrinsic essential predications, Saenz writes, "Merely pointing to God as an answer to "what makes $<$ God is omnibenevolent> true?" is explanatorily empty." ${ }^{\prime 9}$ In short, Saenz maintains that how concrete individuals are can be explanatory, but those individuals themselves cannot be. According to DTS, however, God himself is the truthmaker for intrinsic essential divine predications, and according to Brower's broader perspective on truthmakers, Plato alone-not how Plato is - is the truthmaker for "Plato is human." On the basis of these explanatory shortcomings, Saenz concludes that DTS should be rejected.

An initial thing to note about Saenz's first objection is that it is generally accepted among truthmaker theorists that concrete individuals alone can serve as truthmakers for intrinsic essential predications. ${ }^{10}$ This means that, while Saenz describes the focus of his attack as Brower's DTS, his primary target is actually a widely supported doctrine within the truthmaker com-

\footnotetext{
"Brower, "Making Sense of Divine Simplicity" and "Simplicity and Aseity."

"Saenz, "Against Divine Truthmaker Simplicity," 463-464.

${ }^{8}$ Saenz, "Against Divine Truthmaker Simplicity," 464.

"Saenz ,"Against Divine Truthmaker Simplicity," 468.

${ }^{10}$ E.g., Bigelow, The Reality of Numbers, 128; Lewis, "Armstrong on Combinatorial Possibility," 204; and Rodriguez-Pereyra, "Truthmakers," 192.
} 
munity that stands behind DTS. This point is not an objection, but it does highlight that Saenz's choice of target sets the bar for the success of his argument rather high.

In a recent attempt to defuse Saenz's first objection, Timothy Pawl appeals to the following distinction between metaphysical explanation and epistemic explanation that has been articulated by Karen Bennett: ${ }^{11}$

Metaphysical Explanation: "To say that one thing explains ${ }_{\mathrm{M}}$ another is to say that the first fully accounts for the second, that the first makes the second exist or obtain or happen."

Epistemic Explanation: "To say that one things explains $\mathrm{E}_{\mathrm{E}}$ another is to say that the first renders the second intelligible, sheds light on how or why it happened, or perhaps puts an end to a line of questioning."

\section{In response to Saenz, Pawl then argues:}

On Bennett's view, the grounding of truths in things (truthmaking) only requires metaphysical explanation, not epistemic explanation. ... Now, being that in virtue of which a proposition is true does not carry a requirement that the thing in virtue of which it is true be structured, or that it answer "why" questions satisfactorily. Or, at very least, if being that in virtue of which a truth is true requires structure and answering "why" questions satisfactorily, that hasn't been shown. Brower's sense of "explain" is closer to Bennett's metaphysical sense than it is to her epistemic sense. It seems to me that Brower and his compatriots should deny, along with Bennett, that truthmakers must epistemically explain the truths they make true. ${ }^{12}$

Thus, while Saenz argues that because Brower's DTS fails explanatorily, it fails to be correct, Pawl argues that DTS fails explanatorily in only one sense but that it succeeds explanatorily in another sense. I agree with Pawl that Saenz's charge of explanatory inadequacy is faulty, and I think Pawl is correct in thinking that different senses of explanation are being conflated by Saenz. However, I think that Pawl's use of Bennett's distinctions results in conceding too much to Saenz.

The central reason is that metaphysical explanations explain. As such, they render things intelligible, shed light on how or why things happen, and put an end to certain lines of questioning. According to Bennett, statements of the following form can be true:

(E1) $X$ explains $_{\mathrm{M}} Y$, but $X$ does not explain ${ }_{\mathrm{E}} Y$.

Since Bennett's metaphysical explanation involves "fully accounting for" something, and epistemic explanation involves shedding light on things, this means that statements of the following form should be true as well:

\footnotetext{
${ }^{11}$ Bennett, Making Things Up, 61.

${ }^{12}$ Pawl, "In Defense of Divine Truthmaker Simplicity." Pawl's text is drawn from a conference presentation. A version of this presentation, perhaps somewhat revised, will appear in Res Philosophica.
} 
(E2) X fully accounts for $Y$, but $X$ does not shed any light on $Y$.

However, this statement seems extremely counterintuitive, if not strange. Bennett's characterization of metaphysical explanations thus seems problematic.

Pawl grants that truthmakers do not do the things that epistemic explanations do and thereby concedes that Saenz is correct in maintaining that appealing to concrete entities as truthmakers falls short explanatorily. In fact, Pawl seems to concede that appeals to any kind of truthmakers (and not simply appeals to concrete entities as truthmakers) fall short of the explanatory ideal set by epistemic explanations. (There are even indications that Pawl may concede that explanations in metaphysics in general fall short of this ideal.) However, Pawl wants to claim that falling short in this fashion is not problematic. I think these concessions should be resisted.

In contrast to metaphysical explanations, epistemic explanations are supposed to put an end to lines of questioning. But here are some lines of questioning to which truthmaker explanations put an end:

(T1) Why is $<$ p $>$ true?

(T2) What makes $<$ p $>$ true?

(T3) What grounds the truth of $<\mathrm{p}>$ ?

(T4) How is the truth of $<p>$ grounded in reality?

(T5) What sort of grounding of the truth of $\langle\mathrm{p}>$ is provided by its truthmaker?

(T6) What sort of entity is it that grounds the truth of $<p>$ ?

(T7) Do different categories of truths have different grounds?

(T8) Do true intrinsic predications have different sorts of truthmakers than true extrinsic predications?

(T9) Do true essential predications have different sorts of truthmakers than true accidental predications?

(T10) If the truth of ' $a$ is $F^{\prime}$ is grounded in or made true by how a is, is how $a$ is an entity? If so, what sort of entity is it?

Granted, there might be some lines of questioning that metaphysical explanations in general or truthmaker explanations in particular fail to bring to an end. But in itself this is no objection. It is no objection to the explanations of spacetime provided by the equations of Einstein's theory of relativity that they fail to explain why pondering the vastness of spacetime tends to fill us with a sense of awe. Thus, instead of conceding to Saenz that appeals to particular kinds of truthmakers (and perhaps metaphysical explanations in general) fall short explanatorily in some sense, I contend that reflection on the nature of the metaphysical explanations provided by truthmakers reveals that they do in fact explain (i.e., render 
things intelligible, shed light on how or why things happen, and put an end to certain lines of questioning).

While Bennett's distinction between metaphysical and epistemic explanation does not help to explain where Saenz's first objection goes wrong, I think that Pawl is correct in suggesting that at least some of the time Saenz confuses different senses of "explanation" that need to be distinguished. I propose that one relevant distinction is between things in reality that are responsible for a proposition's being true and speech acts performed to describe those things. For example, if someone asks why a helium atom is positively charged, the explanation will be that the atom's nucleus contains two positively charged protons and two neutrally charged neutrons while its electron shell contains only one negatively charged electron. On the one hand, there are the number, kinds, and arrangement of things in reality - the protons, neutrons, electrons, and the atomic structure. On the other hand, there is the sentence or speech act whose content is $<$ The atom's nucleus contains two positively charged protons and two neutrally charged neutrons while its electron shell contains only one negatively charged electron $>$. In some sense, either one of these could be considered the explanation of the atom's positive charge. From one perspective, what answers the relevant why-question is the existence of more protons than electrons within the atom. From another perspective, however, what answers the question is what Niels said to Ernest when he said "The atom's nucleus contains two positively charged protons and two neutrally charged neutrons while its electron shell contains only one negatively charged electron."

Saenz makes a point that seems to trade on an implicit conflation of these two senses of explanation when he writes, "Merely pointing to God as an answer to 'what makes <God is omnibenevolent $>$ true?' is explanatorily empty." 13 Saenz is asking us to imagine a communicative situation where a why-question has been asked but where the would-be explainer does nothing more than referentially designate God. ${ }^{14} \mathrm{~A}$ response that consisted of a single-word answer like this would seem to be conversationally inappropriate and to fail to satisfy the explanatory demands of the situation. However, the fuller truthmaker answer would not simply be the single-word answer "God." Rather, it would involve a story about the ways in which truth-bearers are made true by things in reality, the kinds of things that can serve as truth-bearers and truthmakers, and whatever relations of necessitation obtain between the two. Thus, the fact such a single-word speech act of the sort envisioned would violate relevant conversational norms does not show that individual entities cannot serve as metaphysical

\footnotetext{
${ }^{13}$ Saenz, "Against Divine Truthmaker Simplicity," 468.

${ }^{14}$ Saenz ("Against Divine Truthmaker Simplicity," 467) seems to be doing the same sort of thing in the following passage: "Insofar as truthmakers are supposed to metaphysically explain why truths are true (as Brower himself accepts), then merely appealing to a thing in order to explain why intrinsic essential claims about that thing are true is to provide a truthmaker that is too course-grained."
} 
grounds of truth-nor does it show that they cannot function in illuminating metaphysical explanations of important philosophical phenomena.

Furthermore, in the domain of reality (as opposed to speech acts), Saenz asserts truthmaker explanations violate structural constraints on explanations:

Plato, the concrete being, is just not rich enough to provide, on his own, a metaphysical ground of the truth of $<$ Plato is a human $>.{ }^{15}$

There needs to be a kind match between what is true and its truthmaker. If it is true that something is some way, then what makes it true must be structured in the right kind of way if it is to explain why the predication applies to it. Plato is just not structured in the way he needs to be if he is to explain why "is a human" applies to him. But then Plato cannot explain why $<$ Plato is a human> is true. ${ }^{16}$

Insofar as truthmakers are supposed to metaphysically explain why truths are true (as Brower himself accepts), then merely appealing to a thing in order to explain why intrinsic essential claims about that thing are true is to provide a truthmaker that is too course-grained. We (including Armstrong) need to dig deeper, and provide more structure in our ontology, if we want satisfactory truthmakers here. ${ }^{17}$

Saenz thus asserts that a truthmaker must have some appropriate structure that corresponds in some way to the structure of what it makes true. However, truthmaker theory denies these claims and indeed to a certain extent is built upon their denial. Simply asserting a view that is contrary to truthmaker theory fails to show the latter to be false.

Moreover, it seems straightforwardly false to claim that an explanans can never have less structure than its explanandum. This is tantamount to claiming that the complex must always be explained in terms of the equally complex. As a general constraint on explanation, this seems quite unintuitive. Consider the familiar Newtonian equation for universal gravitation:

(G) $F=G\left(m_{1} \times m_{2}\right) / r^{2}$

Does $G$ have as much structure as the full range of physical phenomena whose behavior it can explain? It is difficult to see how this can be so. Similar thoughts apply to any case where a universally quantified law of nature is capable of explaining a broad range of phenomena.

Saenz thus owes us a more detailed explanation of what constraints on metaphysical explanations truthmaker explanations allegedly fail to satisfy and why appeals to concrete individuals with less structure than the truths they purport to ground are supposed to be explanatorily empty. Because Saenz has not done this, his first objection to DTS cannot be deemed successful.

\footnotetext{
${ }^{15}$ Saenz, "Against Divine Truthmaker Simplicity," 464.

${ }^{16}$ Saenz, "Against Divine Truthmaker Simplicity," 465.

${ }^{17}$ Saenz, "Against Divine Truthmaker Simplicity," 467.
} 
II.

Saenz's second objection to DTS ${ }^{18}$ concerns a puzzle about the choice between the following claims:

(1) God is wise because God is divine. ${ }^{19}$

(2) God is divine, at least in part, because God is wise. ${ }^{20}$

These claims concern what Saenz calls a "priority ordering between God's intrinsic essential predications" ${ }^{21}$ - either predications of God's wisdom are explanatorily prior to predications of God's divinity or predications of God's divinity are explanatorily prior to predications of God's wisdom. Saenz contends that a choice between (1) and (2) must be made because they represent "jointly exhaustive, mutually exclusive, positions":

Jointly exhaustive because it is just false that the truth of $<$ God is wise $>$ is not in any way explanatorily related to the truth of $<$ God is divine $>$. . . Mutually exclusive because (1) and (2) cannot both be true on pain of violating the irreflexivity of explanation. ${ }^{22}$

Saenz notes that many theists, including Brower, opt for (1). Brower, for example, writes:

Traditional theists standardly derive the intrinsic divine attributes (or better, the truth of predications involving them) from their understanding of the divine nature. That is to say, they take God to be not only good, powerful, wise, and just, but to be all these things in virtue of being divine. ${ }^{23}$

Saenz argues that there are three ways the proponent of divine simplicity can understand this preference for (1) over (2):

(P1) Maintain that the explanatory priority of predications of God's divinity over predications of God's wisdom is a purely conceptual matter;

(P2) Maintain that the explanatory priority of predications of God's divinity over predications of God's wisdom is a non-conceptual matter that is based upon a dependency in reality; or

(P3) Take the explanatory priority of predications of God's divinity over predications of God's wisdom to be a brute, unexplained fact.

Saenz argues that each of these options is problematic for the proponent of DTS and concludes that as a result DTS - and indeed any account of divine simplicity - should be rejected.

\footnotetext{
${ }^{18}$ Saenz, "Against Divine Truthmaker Simplicity," sec. 2.

${ }^{19}$ Saenz, "Against Divine Truthmaker Simplicity," 468.

${ }^{20}$ Saenz, "Against Divine Truthmaker Simplicity," 469.

${ }^{21}$ Saenz, "Against Divine Truthmaker Simplicity," 468.

${ }^{22}$ Saenz, "Against Divine Truthmaker Simplicity," 469.

${ }^{23}$ Brower, "Making Sense of Divine Simplicity," 117.
} 
The first point I would like to make about this objection is that the doctrine of divine simplicity does not seem to require theists to accept the central assumption behind Saenz's dilemma, viz., that " $t \mathrm{t}]$ here exists a kind of priority ordering between God's intrinsic essential predications." ${ }^{24}$ If God is simple, and God's divinity and God's wisdom are not ontologically distinct, it seems open to the proponent of divine simplicity to claim that predications regarding God's divinity do not stand in relations of explanatory priority (or dependency) to predications of God's wisdom. In other words, the dilemma that Saenz is concerned with in his second objection takes aim at the doctrine of divine simplicity only when it is combined with an additional doctrine. Thus, in a way that is reminiscent of Saenz's first objection, the present objection is not a fully direct attack on DTS itself.

Saenz offers the following reason for thinking there are relations of explanatory priority and dependency between distinct divine intrinsic essential predications:

God's intrinsic essential predications are not simply a list of predications every one of which is independent from every other. They are rather a unified and elegant lot. ${ }^{25}$

However, standing in relations of explanatory priority and dependency is only one way in which a set of predications can be unified rather than completely disparate. For example, two predications can be unified in virtue of being necessarily coextensive. Relations of mutual entailment might obtain between the predications without any of them being more fundamental than any other. Moreover, they might be unified in virtue of having the same metaphysical ground. Thus, explanatory priority and dependency is only one kind of glue that might unify a set of predications.

Pawl responds to Saenz's second objection by again appealing to the distinction between metaphysical and epistemic explanation and arguing as follows:

I see no reason to think that the proponent of Divine Truthmaker Simplicity requires an epistemic reading of the "because" in (1) or (2). On a metaphysical reading of the explanation claims, the proponent of Divine Truthmaker Simplicity should say that neither predication is true because of the other (in Bennett's metaphysical sense). Rather, both are true because of God. This response denies the need for an epistemic explanation of the form Saenz is asking for in his initial question and his concluding challenge. Rather than an epistemic explanation, there's a metaphysical explanation (in Bennett's sense). And rather than that metaphysical explanation holding between two propositions, that God is wise, that God is divine, it holds instead between God and each proposition individually. ${ }^{26}$

\footnotetext{
${ }^{24}$ Saenz, "Against Divine Truthmaker Simplicity," 468.

${ }^{25}$ Saenz, "Against Divine Truthmaker Simplicity," 468.

${ }^{26}$ Pawl, "In Defense of Divine Truthmaker Simplicity."
} 
Although I have indicated above why I think that Pawl should not rely upon Bennett's distinctions between kinds of explanation, I agree with Pawl that the proponent of divine simplicity should insist upon metaphysically explaining (the ground of truth of) predications of God's divinity and God's wisdom in God himself. In one sense, this amounts to a rejection of the dilemma for divine simplicity as represented in Saenz's second objection - at least in the terms that it was posed.

Augustine, Anselm, Aquinas, and Brower all endorse P1. P2 represents the rejection of divine simplicity, since it asserts there is a real distinction and dependency relation between God's divinity and God's wisdom. Proponents of divine simplicity also do not endorse P3. Saenz offers the following argument against option P1:

It is a conceptual truth that anyone who satisfies BACHELOR does so in virtue of satisfying UNMARRIED and MALE since BACHELOR decomposes into UNMARRIED and MALE. And it is a conceptual falsehood that anyone who satisfies UNMARRIED and MALE does so in virtue of satisfying BACHELOR since neither UNMARRIED nor MALE decomposes into bachelor. So the pattern of dependency exemplified in (3) [Bill is a bachelor because Bill is an unmarried male] is explained by appealing to the pattern of dependency exemplified by the concepts involved in (3). Unfortunately, this kind of explanation will not work in our present case. After all, (2) is a conceptually coherent claim. One could defend (2) against (1) without being confused about the concepts WISDOM and DIVINITY. It is a live debate whether we should accept (1) over (2), as it would not be if the disagreement over them boiled down to a disagreement over the concepts involved (as it plausibly does in the bachelor case). (1) is therefore not a conceptual truth. Brower agrees when, to paraphrase him, he says that it is a real question whether the list of divine predications (God is good, powerful, wise, just) depend on the predication of God's being divine, but that it is at least coherent to say that they do. But it wouldn't be a real question if (1) were a conceptual truth. If (1) were a conceptual truth, the question would be settled decisively in favor of (1). ${ }^{27}$

Saenz is suggesting that conceptual questions are easily answered, conceptual truths easily discerned, and conceptual disputes easily resolved. If that were the case, the analysis of the concepts EPISTEMIC JUSTIFICATION, PERSONAL IDENTITY, and MORALLY CORRECT ACTION would have been resolved long ago. It is a live question how the concept of EPISTEMIC JUSTIFICATION is related to the concepts of RELIABILITY, EVIDENCE, COHERENCE, EPISTEMIC DUTY, and EPISTEMIC VIRTUE. Furthermore, one epistemologist can think JUSTIFIED BELIEF is conceptually prior to KNOWLEDGE while another can think that the reverse is true without either one of them being guilty of elementary confusions about the concepts involved. To think that "It is a live debate whether $\langle\mathrm{p}\rangle$ " and "It is a real question whether $\langle\mathrm{p}\rangle$ " both entail "It is not a conceptual question whether $\langle\mathrm{p}>$ " seems to indicate a lack of familiarity with

\footnotetext{
${ }^{27}$ Saenz, "Against Divine Truthmaker Simplicity," 470.
} 
the practice of philosophy. The analysis of philosophically interesting concepts is much more difficult and fraught with subtle disagreements than the analysis of simple concepts like BACHELOR.

Saenz mistakenly claims that Brower seems to agree with him that (1) and (2) are not dealing with purely conceptual matters. ${ }^{28}$ Brower makes it quite clear in several places that he thinks whatever distinctions there are between divine essential attributes are merely conceptual and concern the sense rather than the reference of these terms. For example, Brower writes:

For even if God is absolutely simple, and hence identical with each of his constituents, we can still draw a conceptual distinction between God's nature and his justice or power (for surely expressions such as 'God's nature,' 'God's justice,' and 'God's power' are distinct in sense, even if not in reference). ${ }^{29}$

What is needed is an account that is both thin enough to preserve the categorial neutrality of referents of expressions of the form ' $a$ 's $F$-ness,' while at the same time thick enough to enable us to distinguish such referents when they are either in fact distinct (as in the case of Socrates' nature and Socrates' goodness) or merely conceptually distinct (as in the case of God's nature and God's goodness). ${ }^{30}$

Indeed, Brower makes it abundantly clear that he is following a long tradition of distinguishing between merely conceptual distinctions among the divine essential attributes and any real distinctions between them. For example, Brower cites Eleonore Stump and Norman Kretzmann, who write:

According to the doctrine of simplicity, what human beings call God's omnipotence or God's omniscience is the single eternal action considered under descriptions they find variously illuminating, or recognized by them under different kinds of effects or manifestations of it. What the doctrine requires one to understand about all the designations for the divine attributes is that they are all identical in reference but different in sense, referring in various ways to the one actual entity which is God himself or designating various manifestations of it. 'Perfect power' and 'perfect knowledge' are precise analogues for 'the morning star' and 'the evening star': non-synonymous expressions designating quite distinct manifestations of one and the same thing.... The respect in which God is utterly devoid of real distinctions does not, after all, preclude our conceptually distinguishing God's actions in the world from one another or from God himself. ${ }^{31}$

While Plato's wisdom and Plato's justice are distinct in both sense and reference, God's wisdom and God's justice are distinct only in sense. Yet if the distinctions between these divine attributes are merely conceptual and not based in reality, it is clear that whatever priority or dependence there is between predications regarding these attributes is also purely conceptual rather than real.

\footnotetext{
${ }^{28}$ Saenz, "Against Divine Truthmaker Simplicity," 470.

${ }^{29}$ Brower, "Making Sense of Divine Simplicity," 16

${ }^{30}$ Brower, "Making Sense of Divine Simplicity," 23.

${ }^{31}$ Stump and Kretzmann, "Absolute Simplicity," 356-357.
} 
In light of the reasons articulated in this section, I conclude that Saenz's second (and final) objection to DTS fails to show that DTS should be rejected.

III.

Saenz has attempted to undermine Brower's recent articulation of divine truthmaker simplicity by arguing that the latter runs afoul of various constraints on metaphysical explanations. Saenz's two main objections are aimed at doctrines that either lie behind (objection one) or are often associated with (objection two) DTS. In each case, I have argued that Saenz makes implausible or at least unsubstantiated claims about what metaphysical explanation requires and have suggested ways in which the proponent of DTS can respond.

University at Buffalo

\section{References}

Bennett, Karen. 2017. Making Things Up (Oxford University Press). https://doi.org/10.1093/oso/9780199682683.001.0001

Bigelow, John. 1988. The Reality of Numbers: A Physicalist's Philosophy of Mathematics (Clarendon Press).

Brower, Jeffrey E. 2008. "Making Sense of Divine Simplicity." Faith and Philosophy 25: 3-30. https://doi.org/10.5840/faithphil20082511

Brower, Jeffrey E. 2009. "Simplicity and Aseity." In The Oxford Handbook of Philosophical Theology, edited by Michael Rea and Thomas Flint (Oxford University Press), 105-128. https://doi.org/10.1093/oxfordhb/9780199289202.003.0006

King, Jeffrey C. 2011. "Structured Propositions." In the Stanford Encyclopedia of Philosophy, edited by Edward N. Zalta, https://plato.stanford.edu/entries/propositions-structured/.

Lewis, David K. 1999. "Armstrong on Combinatorial Possibility." In Papers in Metaphysics and Epistemology (Cambridge University Press), 196-214.

https://doi.org/10.1017/CBO9780511625343.013

MacBride, Fraser. 2013. "Truthmakers." In the Stanford Encyclopedia of Philosophy, edited by Edward N. Zalta, https://plato.stanford.edu/entries/truthmakers/.

Pawl, Timothy. 2018. "In Defense of Divine Truthmaker Simplicity." Presented at the 2018 Henle Conference ("Scholarship and Stewardship: A Conference in Honor of Father Theodore Vitali"), Saint Louis University, March 10, 2018. (A version of this paper, somewhat revised, will appear in Res Philosophica.)

Plantinga, Alvin. 1980. Does God Have a Nature? (Marquette University Press).

Rodriguez-Pereyra, Gonzalo. 2006. "Truthmakers." Philosophy Compass 1: 186-200. https://doi.org/10.1111/j.1747-9991.2006.00018.x

Saenz, Noël B. 2014. "Against Divine Truthmaker Simplicity." Faith and Philosophy 31: 460-474. https://doi.org/10.5840/faithphil2014121725

Stump, Eleonore, and Norman Kretzmann. 1985. "Absolute Simplicity." Faith and Philosophy 2: 353-382. https://doi.org/10.5840/faithphil19852449 